\title{
Jurnal Ilmu Kesehatan Masyarakat
} (The Public Health Science Journal)

Journal Homepage: http://journals.stikim.ac.id/index.php/jikm

\section{Pengaruh Jenis Berita COVID-19 terhadap Tingkat Kecemasan Mahasiswa}

\author{
Meira Oryza Vidia Utami ${ }^{1} *$, Fadjrina Hapsari Woro Ayuningbudi ${ }^{2}$, Tafia Afina \\ Putri $^{3}$, Fitri Ariyanti Abidin ${ }^{4}$ \\ ${ }^{1-3}$ Fakultas Psikologi, Universitas Padjadjaran \\ ${ }^{4}$ Departemen Psikologi Umum dan Eksperimen Fakultas Psikologi Universitas Padjadjaran \\ ${ }^{4}$ Pusat Studi Inovasi dan Penelitian Fakultas Psikologi Universitas Padjadjaran
}

\begin{abstract}
Abstrak
Seiring dengan situasi pandemi COVID-19, media massa didominasi dengan pemberitaan mengenai perkembangan COVID-19, baik berita positif maupun negatif. Munculnya berbagai berita ini berperan besar dalam memicu kecemasan, terutama berita yang bersifat negatif. Atas dasar hal tersebut, penelitian ini dilakukan dengan tujuan melihat pengaruh jenis berita perkembangan COVID-19 (positif, negatif, dan netral) terhadap tingkat kecemasan mahasiswa. Pendekatan metode eksperimental menggunakan rancangan simple randomized pretest-posttest design. Responden merupakan 75 mahasiswa (laki-laki=9, perempuan=66), dibagi menjadi kelompok eksperimen A (diberikan berita negatif, $n=26$ ), kelompok eksperimen $B$ (diberikan berita positif, $n=25$ ) dan kelompok kontrol (diberikan berita netral, $n=24$ ). Kecemasan responden diukur sebelum dan sesudah perlakuan menggunakan Coronavirus Anxiety Scale (CAS) dan Generalized Anxiety Disorder (GAD-7). Hasil uji one-way ANOVA menunjukkan bahwa tidak terdapat perbedaan selisih tingkat kecemasan yang signifikan antara kelompok eksperimen $A$, eksperimen $B$, dan kontrol $(F(2)=0,1468, p>0,05)$. Tidak adanya perbedaan yang signifikan disebabkan oleh tidak munculnya setelah membaca berita. Emotional arousal tidak muncul dikarenakan pengalaman responden mendapatkan paparan berulang berita negatif sebelum penelitian dan karena perbedaan individu dalam pengalaman emotional arousal. Dengan demikian, dampak paparan berita negatif pada kesehatan mental tidak terlalu signifikan setelah pandemik COVID-I 9 dialami cukup lama.
\end{abstract}

Kata Kunci: Berita, COVID-19, emotional arousal, kecemasan, pandemi.

\begin{abstract}
Along with the COVID-19 pandemic, the mass media was dominated by positive and negative news about the development of COVID-19. The emergence of this various news plays a major role in triggering anxiety, especially news that is negative. Based on this phenomenon, the present study was conducted to investigate the effect of news types (positive, negative, and neutral) on undergraduate student anxiety. Respondents are 75 undergraduate students (male = 9, female $=66$ ); was divided into experimental group $A$ (was given the negative news, $n=26$ ), experimental group $B$ (was given the positive news, $n=25$ ), and control group (was given neutral news, $n=24$ ). Respondents' anxiety was measured before and after the treatment using the Coronavirus Anxiety Scale (CAS) and Generalized Anxiety Disorder (GAD-7). The one-way ANOVA test showed that there was no significant difference in the level of anxiety between the experimental group $A$, experimental group $B$, and control group $(F$ $(2)=0.1468, p>0.05)$. The insignificant difference due to the absence of emotional arousal after reading the news. Emotional arousal absences could be due to repeated exposure to the news before the study or individual differences in emotional arousal experiences. Thus, the effect of negative news on mental health is not significant after a pandemic has been experienced for quite a long time.
\end{abstract}

Keywords: News, COVID-19, emotional arousal, anxiety, pandemic.

Korespondensi*: Meira Oryza Vidia Utami, Fakultas Psikologi, Universitas Padjadjaran, Jl. Raya Bandung-Sumedang KM. 21 Jatinangor - Sumedang, E-mail: meiral8002@mail.unpad.ac.id, No.Telp: +62822347505 /4 


\section{Pendahuluan}

Pandemi COVID-19 sudah menjangkau hampir seluruh negara di dunia pada tanggal 9 Maret 2020, tidak terkecuali Indonesia. Di Indonesia, setelah kasus pertama muncul, COVID-19 mulai menyebar ke berbagai tempat di Indonesia dan kasusnya masih terus meningkat tajam. ${ }^{1}$ Penelitian menunjukkan bahwa COVID-19 berpengaruh terhadap depresi dan kecemasan (khususnya General Anxiety Disorder) pada masyarakat umum dan khususnya pada mahasiswa. ${ }^{2,3}$

Berkaitan dengan kondisi pandemi COVID-19, media massa didominasi dengan pemberitaan mengenai perkembangan COVID-19 baik berita positif maupun negatif. Berita adalah sebuah bentuk laporan yang disampaikan kepada khalayak umum melalui media massa. Laporan tersebut dapat berupa peristiwa, gagasan, atau fakta yang biasanya menarik perhatian banyak orang dan penting untuk disampaikan. ${ }^{4}$ Jenis berita dapat dibedakan menjadi straight news, spot press, hard news, dan soft news. 5-8

Berita juga bisa dikategorikan sebagai berita positif dan berita negatif. Berita positif adalah berita yang berisi suatu hal yang positif atau menegaskan. ${ }^{9}$ Berita positif dapat berbentuk straight news, spot press, soft news, bahkan hard news. Berita positif yang terkait pada masa pandemi ini cenderung termasuk dalam jenis berita spot press, karena isinya memiliki nilai yang tinggi dan masyarakat sangat menanti-nantikan berita positif pada masa pandemi. Contoh dari berita positif terkait perkembangan COVID-19 diantaranya berita mengenai perkembangan vaksin COVID-19 yang terlihat menjanjikan, penurunan tingkat kematian akibat COVID-19 di beberapa daerah di Indonesia atau meningkatnya angka kesembuhan di Indonesia. ${ }^{10-12}$ Sedangkan berita negatif merupakan berita yang didalamnya berisi suatu hal yang tidak diinginkan atau cenderung tidak ingin diterima. Dalam masa pandemi ini, berita negatif cenderung termasuk dalam jenis berita hard news, karena isinya berisi hal yang "tidak menyenangkan" dan terkait oleh masalah sosial yang harus segera dipublikasikan pada masyarakat. Contoh berita negatif terkait perkembangan COVID-19 misalnya berita mengenai peningkatan angka kematian yang diakibatkan COVID-19, buruknya keadaan COVID-19 di suatu daerah, atau perkiraan puncak kasus COVID-19 tertinggi di negara Indonesia. ${ }^{13-15}$

Munculnya berbagai berita positif dan negatif ini dapat berperan besar dalam memicu kecemasan dan kepanikan masyarakat di saat pandemi COVID-19. Hal ini dapat dilihat dari penelitian yang membuktikan bahwa menerima berita negatif dapat menimbulkan emotional arousal. Emotional arousal adalah ketergugahan emosi, baik emosi negatif atau positif yang diinterpretasi individu dari situasi yang intens. ${ }^{16-17}$ Selain itu, berdasarkan penelitian mengenai efek dari misleading berita, seseorang dapat mengalami stres, ketakutan, kecemasan, bahkan kemarahan setelah membaca berita. $^{18}$ Di sisi lain, membaca berita positif terkait perkembangan COVID-19 memiliki potensi menurunkan tingkat stres dan kecemasan karena dapat menimbulkan perasaan positif dan menyenangkan bagi seseorang. ${ }^{19}$

Melihat banyaknya perubahan yang terjadi ketika masa pandemi COVID-19, termasuk pada tingkat kecemasan yang beriringan dengan banyaknya paparan berita positif maupun negatif terkait perkembangan COVID-19 yang muncul, maka penelitian ini bertujuan untuk mengetahui apakah jenis berita perkembangan COVID-19 mempengaruhi tingkat kecemasan mahasiswa.

\section{Metode}

Penelitian ini menggunakan metode eksperimental dengan rancangan simple randomized pretest-posttest design (gambar 1). Pada seluruh responden, dilakukan pre-test untuk mengukur tingkat 
kecemasan menggunakan alat ukur Coronavirus Anxiety Scale (CAS) dan Generalized Anxiety Disorder (GAD-7), sebelum membaca berita perkembangan COVID-19. Setelah itu, peneliti membagi responden penelitian menggunakan metode simple random sampling menggunakan undian menjadi tiga kelompok berdasarkan hasil dari pre-test. Setiap kelompok terdiri dari responden dengan tingkat kecemasan tinggi ( $\mathrm{n}=8$ atau 9$)$, sedang $(\mathrm{n}=8$ atau 9$)$ dan rendah ( $\mathrm{n}=8$ atau 9 ). Kemudian, ketiga kelompok, yaitu kelompok eksperimen A, kelompok eksperimen B, dan kelompok kontrol diberikan perlakuan berbeda berupa berita untuk dibaca. Berita negatif untuk kelompok eksperimen A, berita positif untuk kelompok eksperimen
B dan berita netral untuk kelompok kontrol. Berita diberikan dalam bentuk tayangan screen sharing yang ditampilkan pada layar zoom meeting. Setelah selesai membaca, ketiga kelompok diberikan post-test untuk mengukur tingkat kecemasannya. Alat ukur yang digunakan sama dengan alat ukur pre-test, yaitu Coronavirus Anxiety Scale (CAS) dan Generalized Anxiety Disorder (GAD-7). Hasil pre dan post-test dibandingkan untuk melihat pengaruh pemberian jenis berita terhadap tingkat kecemasan. Terdapat beberapa variabel kontrol dalam penelitian, meliputi alat ukur, jenis berita, instruksi penelitian, waktu penelitian, dan homogenitas kelompok saat pretest.

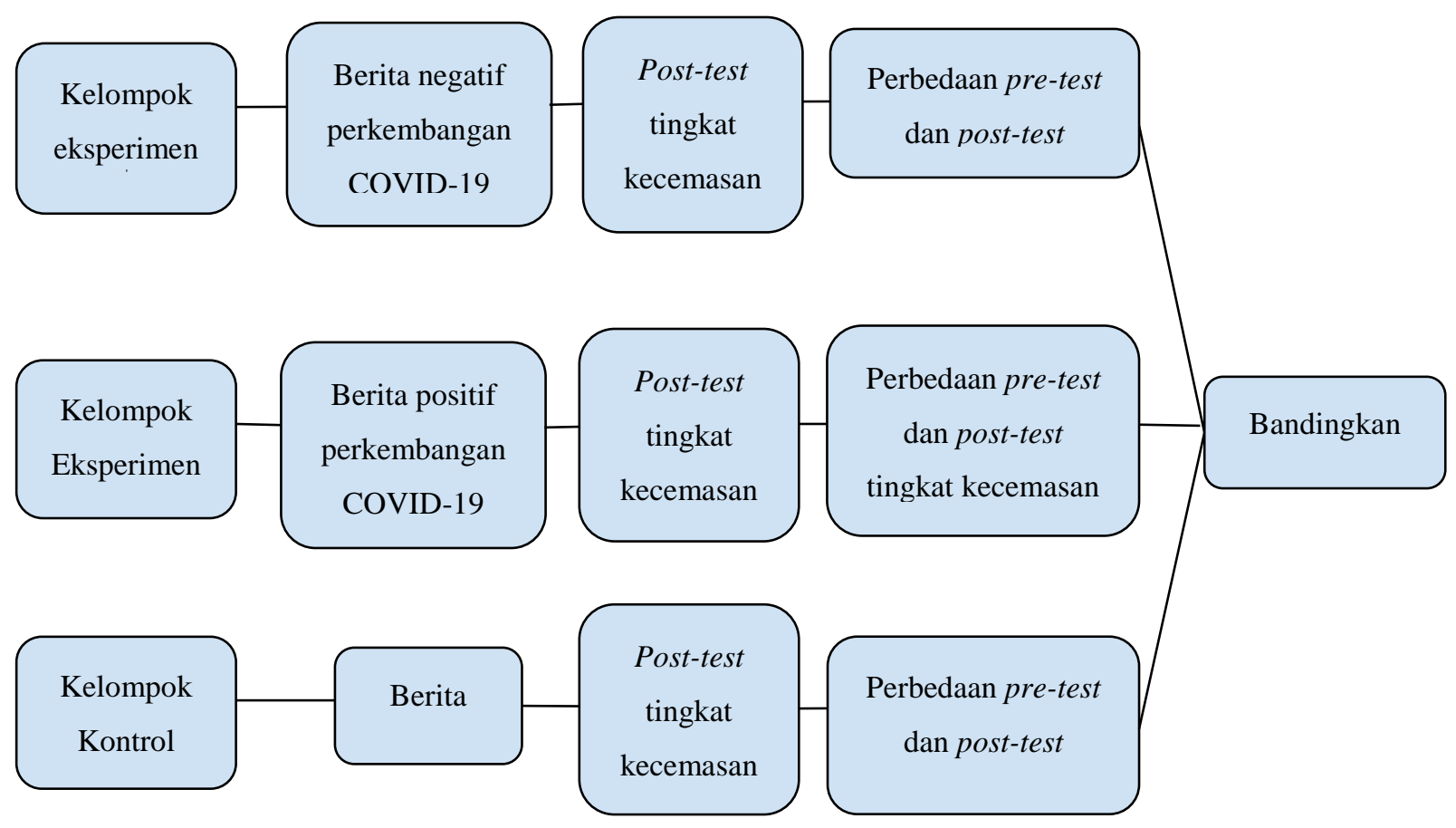

Gambar 1. Rancangan Penelitian

Populasi dan karakteristik responden adalah mahasiswa/i tahun kedua dan ketiga. Responden mahasiswa dipilih dengan alasan berdasarkan tingkat pendidikan, orang-orang di tingkat perguruan tinggi relatif memiliki tingkat kecemasan lebih rendah dibanding mereka yang berada di tingkat SMA atau lebih rendah. ${ }^{20}$ Tujuh puluh lima responden yang telah menandatangani surat kesediaan mengikuti penelitian terbagi menjadi mahasiswa tingkat tiga $(\mathrm{n}=50)$ dan mahasiswa tingkat dua $(n=25)$. Sebagian besar responden adalah perempuan $(n=66)$ 
dibanding responden laki-laki $(\mathrm{n}=9)$. Jumlah responden dalam setiap kelompok yaitu kelompok eksperimen A $(n=26)$, kelompok eksperimen B $(n=25)$, dan kelompok kontrol $(n=24)$.

Alat ukur yang digunakan untuk mengukur kecemasan dalam penelitian ini adalah Coronavirus Anxiety Scale (CAS) dan Generalized Anxiety Disorder (GAD7). CAS merupakan pengukuran terjadinya kecemasan disfungsional yang terkait dengan krisis COVID-19, menggunakan pengalaman gejala fisiologis ketakutan dan kecemasan yang dialami responden ketika terpapar berita, informasi, atau pemikiran terkait coronavirus. CAS terdiri dari 5 item yang dinilai menggunakan skala frekuensi 0 (tidak sama sekali) hingga 5 (hampir setiap hari selama 2 minggu terakhir). ${ }^{21}$ Skala yang tinggi pada hasil pengukuran menunjukkan bahwa tingkat kecemasan responden tinggi dan skala yang rendah menunjukkan bahwa tingkat kecemasan responden rendah pula. Item alat ukur CAS diterjemahkan ke dalam bahasa Indonesia oleh peneliti dan setelah itu di-review oleh ahli.

GAD-7 adalah self-report scale singkat untuk mengidentifikasi kemungkinan kasus Generalized Anxiety Disorder (GAD) atau kecemasan dan kekhawatiran berlebihan tentang berbagai macam hal yang terdiri dari 7 item yang dinilai menggunakan skala frekuensi 0-4 dari 2 minggu terakhir, dimana 0 menunjukkan tidak ada gejalasama sekali dan 4 menunjukkan hampir setiap hari. ${ }^{22}$ GAD-7 sudah pernah diterjemahkan dan diuji validitas dan reliabilitasnya di Indonesia. $^{23}$ Validitas internal dan reliabilitas untuk GAD-7 versi Indonesia sudah memuaskan dengan koefisien validitas $0,648-0,800(\mathrm{p}<0,01)$ dan nilai Cronbach's alpha 0,867 .

Dalam penelitian ini, alat ukur CAS dan GAD-7 sama-sama digunakan untuk mengukur tingkat kecemasan menjadi satu alat ukur yang terdiri dari 4 item CAS dan 7 item GAD-7. Reliabilitas alat ukur diuji menggunakan Cronbach's alpha dan diperoleh nilai $\alpha=0,902$. Validitas item diuji menggunakan penghitungan korelasi Pearson Product Moment didapatkan hasil bahwa setiap item memiliki $r>0,227$. Selain alat ukur utama, diberikan juga pertanyaan sebagai data pendukung berupa pertanyaan "Apa yang Anda rasakan setelah membaca berita tadi". Responden memberikan skala 1 sampai 5 (1=sangat tidak nyaman , 5=sangat nyaman)

$$
\text { Prosedur pengambilan data }
$$

dilakukan dengan meminta responden mengisi pre-test berupa kuesioner sekitar satu minggu sebelum penelitian. Setelah data pre-test terkumpul, peneliti melakukan olah data pre-test sebagai screening awal penempatan responden pada kelompok eksperimen A, eksperimen B, dan kelompok kontrol. Kemudian peneliti menghubungi responden kembali untuk mengikuti penelitian.

Data dari hasil pre-test dan post-test adalah data untuk variabel dependen berupa tingkat kecemasan, yang memiliki skala interval dengan rentang skor 11-55. Sebelum dilakukan uji statistik untuk menguji hipotesis, dilakukan uji normalitas dilanjutkan dengan uji homogenitas pada data pre-test dan post-test. Data pre-test dan post-test memiliki varians yang tergolong sama (homogen), selanjutnya dilakukan uji ANOVA untuk melihat perbedaan skor kecemasan 3 kelompok (kelompok eksperimen A, eksperimen B, kelompok kontrol). Skor kecemasan yang dibandingkan adalah skor perbedan pretest dan posttest). Disimpulkan terdapat perbedaan skor jika nilai $\mathrm{p}<\alpha$, dengan nilai $\alpha=0,05$. Analisa data dilakukan dengan menggunakan software SPSS versi 25.

\section{Hasil}

Hasil uji normalitas Shapiro-Wilk menunjukkan bahwa semua data berdistribusi normal, dengan nilai $\mathrm{p}>0,05$ pada semua kelompok. Setelah data terbukti berdistribusi normal, dilakukan uji homogenitas data yang sama menggunakan uji Levene. Hasilnya menunjukkan bahwa semua data pre-test dan post-test tiap 
kelompok bersifat homogen dengan nilai p >0,05 pada semua kelompok data.

Setelah terbukti bahwa data berdistribusi normal dan merupakan data homogen, maka dilakukan uji one-way ANOVA. Uji one-way ANOVA dilakukan terhadap data pre-test terlebih dahulu sebagai bentuk kontrol penelitian. Dari uji tersebut, didapatkan hasil bahwa mean skor kecemasan antar kelompok pada data pretest tidak jauh berbeda (mean kelompok eksperimen $\mathrm{A}=2,80$; mean kelompok eksperimen $\mathrm{B}=3,60 ;$ mean kelompok kontrol $=3,16$ ), dengan nilai $p>0,05$ (tabel 1). Artinya, derajat kecemasan seluruh responden yang berada di tiga kelompok yang berbeda adalah sama.

Selanjutnya, dilakukan pengujian hipotesis perbedaan rata-rata antar tiga kelompok. Adapun skor yang dibandingkan adalah skor selisih tingkat kecemasan yang didapatkan dari skor post- test yang dikurangi oleh skor pre-test. Hasil dari uji one-way ANOVA yang dilakukan menunjukkan bahwa tidak terdapat perbedaan selisih tingkat kecemasan yang signifikan antara kelompok eksperimen A, kelompok eksperimen B, dan kelompok kontrol $(\mathrm{Pv}>0,05)$ (tabel 2). Berdasarkan hal tersebut, diartikan bahwa jenis berita COVID-19 tidak berpengaruh terhadap tingkat kecemasan mahasiswa.

Pengolahan data pendukung dilakukan untuk mengetahui aspek emotional arousal responden dari penelitian ini. Dari tabel 3 dapat dilihat bahwa setiap kelompok memiliki mean skala pertanyaan data pendukung mendekati 3, dimana skala 3 memiliki arti "biasa saja". Hal ini dapat diartikan bahwa hanya ada sedikit, atau tidak ada emotional arousal signifikan yang muncul pada responden penelitian.

Tabel 1. Uji One Way ANOVA Data Pretest

\begin{tabular}{cccccc}
\hline & Sum of Square & df & Mean Square & F & Sig. \\
\hline Between Groups & 89,062 & 2 & 44,531 & 0,747 & 0,478 \\
Within Groups & 4174,719 & 70 & 59,639 & & \\
\hline Total & 4263,781 & 72 & & & \\
\hline
\end{tabular}

Tabel 2. Uji One Way ANOVA Selisih Skor Posttest dan Pretest

\begin{tabular}{cccccc}
\hline & Sum of Squares & df & Mean Square & F & Sig. \\
\hline Between Groups & 148,641 & 2 & 74,320 & 1,468 & 0,237 \\
Within Groups & 3543,578 & 70 & 50,623 & & \\
\hline \multicolumn{1}{c}{ Total } & 3692,219 & 72 & & & \\
\hline
\end{tabular}

Tabel 3. Data Pendukung (Emosi ketika Posttest)

\begin{tabular}{lccc}
\hline \multicolumn{1}{c}{ Kelompok } & Mean & n & Std. deviation \\
\hline Eksperimen1 & 2,80 & 25 & 0,577 \\
Eksperimen2 & 3,60 & 25 & 0,707 \\
Kontrol & 3,14 & 22 & 0,468 \\
\hline \multicolumn{1}{c}{ Total } & 3,18 & & 0,678 \\
\hline
\end{tabular}

\section{Pembahasan}

Penelitian ini bertujuan untuk mengetahui apakah jenis berita perkembangan COVID-19 mempengaruhi tingkat kecemasan mahasiswa. Tiga jenis berita yang diujikan, yaitu berita negatif, berita positif, dan berita netral. Hasil penelitian menunjukkan bahwa jenis berita tidak berpengaruh terhadap tingkat kecemasan mahasiswa. Hasil ini berbeda 
dengan penelitian sebelumnya yang menemukan bahwa berita negatif berdampak pada peningkatan kecemasan. $^{17,24}$ Sebaliknya berita positif berdampak terhadap penurunan kecemasan. ${ }^{19}$ Jika dicermati lebih lanjut, dinamika psikologis yang terjadi mengenai pengaruh berita negatif terhadap kecemasan, diperantarai oleh tergugahnya emosi individu (emotional arousal). ${ }^{17} \mathrm{Hal}$ ini diperkuat oleh penelitian yang menemukan bahwa ketergugahan emosi negatif adalah faktor yang menyebabkan kecemasan. $^{25}$

Berdasarkan data penunjang, emotional arousal yang menjadi kunci adanya perasaan cemas, tidak terjadi dalam penelitian ini. Tidak tergugahnya emosi yang terjadi pada responden penelitian ini dapat dijelaskan melalui dua hal, yaitu paparan berulang pada berita perkembangan COVID-19 dan perbedaan individual pada responden penelitian. Paparan berulang terjadi karena penelitian dilakukan setelah pandemi COVID-19 berlangsung kurang lebih tujuh bulan. Penjelasan ini didukung oleh hasil penelitian lain yang menyatakan bahwa paparan berulang pada suatu bentuk stimulus negatif dapat mengurangi reaktivitas amigdala ketika pemaparan terhadap stimulus negatif dilakukan setelahnya. $^{26}$ Sementara untuk berita positif, kaitan antara terus terpaparnya responden pada berita positif tersebut dengan tidak munculnya emotional arousal yang signifikan dapat dijelaskan oleh penelitian Smith \& Dorman. ${ }^{7}$ Penelitian tersebut membuktikan bahwa sebuah stimulus yang rendah uncertainty-nya (berita positif yang digunakan pada penelitian juga memiliki uncertainty yang rendah), rasa suka kepada stimulus tersebut akan berkurang seiring dengan peningkatan frekuensi paparan terhadap stimulus tersebut. Berkurangnya rasa suka tersebut menyebabkan tidak munculnya emotional arousal yang seharusnya dirasakan ketika membaca berita positif tersebut.
Sementara untuk faktor perbedaan individu, Rusting menyebutkan bahwa kepribadian dan suasana hati juga mampu mempengaruhi proses emotional arousal, baik secara bersama-sama ataupun sendiri. ${ }^{27}$ Selain itu, perbedaan individu juga dapat dicirikan oleh perbedaan dalam merespon stimulus, dimana responden dengan kecemasan sifat tinggi mungkin telah mengembangkan strategi regulasi emosi atau mekanisme coping yang baik untuk meregulasi emosi mereka. ${ }^{27}$

\section{Kesimpulan}

Hasil penelitian menunjukkan bahwa jenis berita COVID-19 tidak mempengaruhi tingkat kecemasan. Paparan berulang berita yang diterima mahasiswa menghambat terjadinya emotional arousal yang signifikan sehingga paparan berita negatif terkait COVID-19 tidak perlu terlalu dikhawatirkan sebagai faktor penentu kecemasan individu setelah pandemic COVID-19 dialami dalam jangka waktu yang cukup lama. Penelitian selanjutnya disarankan untuk melakukan penelitian pendahuluan yang bertujuan menguji emotional arousal yang ditimbulkan oleh tayangan berita yang akan digunakan.

\section{Daftar Pustaka}

1. Syarifah F. Kurva COVID-19 Terus Meningkat, PMI Gaungkan Pentingnya Penggunaan Masker - On Off Liputan6.com. Liputan 6 [Internet]. 10 September 2020 [dikutip 15 Juli 2021]; Tersedia pada: https://www.liputan6.com/onoff/read/4347303/kurva-COVID-19-terusmeningkat-pmi-gaungkan-pentingnyapenggunaan-masker

2. Hyland P, Shevlin M, McBride O, Murphy J, Karatzias T, Bentall RP, et al. Anxiety and depression in the Republic of Ireland during the COVID-19 Pandemic. Acta Psychiatr Scand. 2020;142(3):0-2. Tersedia pada: https://pubmed.ncbi.nlm.nih.gov/32716520/

3. Cao W, Fang Z, Hou G, Han M, Xu X, Dong $J$, et al. The psychological impact of the COVID-19 epidemic on college students in China. Psychiatry Res [Internet]. 2020;287:112934. Tersedia pada: https://doi.org/10.1016/j.psychres.2020.11293 4 
4. Barus SW. Jurnalistik: petunjuk teknis menulis berita. Erlangga; 2010.

5. Rani NLRM. Persepsi Jurnalis dan Praktisi Humas terhadap Nilai Berita. J Ilmu Komun. 2013 Jun 1;10(1). Tersedia pada : https://ojs.uajy.ac.id/index.php/jik/article/view $/ 155$

6. Budiman K. Dasar-Dasar Jurnalistik [Internet]. repository.ung.ac.id. Info Jawa: Pelatihan Jurnalistik; 2005 [cited 2021 Jul 15]. Tersedia pada: https://repository.ung.ac.id/get/kms/127/jurnal istik.pdf

7. Smith GF, Dorfman DD. The Effect of Stimulus Uncertainty on the Relationship Between Frequency of Exposure and Liking. J Pers Soc Psychol. 1975;31(1):150-5. Tersedia pada: https://content.apa.org/record/197508852-001

8. Lehman-wilzig SN, Seletzky M. Hard news , soft news, ' general ' news: The necessity and utility of an intermediate classification. Journal Theory, Pract Crit. 2010;11(1972):3756. Tersedia pada: https://journals.sagepub.com/doi/10.1177/146 4884909350642

9. Sunstein CR, Bobadilla-Suarez S, Lazzaro SC, Sharot T. How people update beliefs about climate change: Good news and bad news. Cornell Law Rev. 2016;23(2013):1-12. Tersedia pada: https://scholarship.law.cornell.edu/clr/vol102/i ss6/1

10. Franedya R. Kabar Baik! Vaksin COVID-19 Ini Ciptakan Antibodi di Lansia. CNBC Indonesia [Internet]. 26 Oktober 2020 [dikutip 15 Juli 2021]; Tersedia pada: https://www.cnbcindonesia.com/tech/2020102 6152336-37-197183/kabar-baik-vaksinCOVID-19-ini-ciptakan-antibodi-di-lansia

11. Anwar MC. Luhut: Tingkat Kematian Akibat COVID-19 di 8 Provinsi Menurun. CNBC Indonesia [Internet]. 21 Oktober 2020 [dikutip 15 Juli 2021]; Tersedia pada: https://www.cnbcindonesia.com/news/202010 21161429-4-196078/luhut-tingkat-kematianakibat-COVID-19-di-8-provinsi-menurun

12. Satgas COVID-19. Persentase Pasien COVID19 Sembuh di Angka 80,5 Persen. CNN Indonesia [Internet]. 26 Oktober 2020 [dikutip 15 Juli 2021]; Tersedia pada: https://www.cnnindonesia.com/nasional/2020 1026091425-25-562663/persentase-pasienCOVID-19-sembuh-di-angka-805-persen

13. Kamil I. 727.122 Kasus COVID-19 dan Angka Kematian yang Memburuk... Halaman all - Kompas.com. KOMPAS.com [Internet]. 30 Desember 2020 [dikutip 17 Juli 2021]; Tersedia pada: https://nasional.kompas.com/read/2020/12/30/
06382771/727122-kasus-COVID-19-danangka-kematian-yang-memburuk?page $=$ all

14. Farasonalia R. Angka Aktif COVID-19 di Semarang Tertinggi di Indonesia, Dinkes Kaget. KOMPAS.com [Internet]. 2 September 2020 [dikutip 17 Juli 2021]; Tersedia pada: https://regional.kompas.com/read/2020/09/02/ 06324651/angka-aktif-COVID-19-disemarang-tertinggi-di-indonesia-dinkes-kaget

15. CNN Indonesia. Epidemiolog Prediksi Puncak COVID-19 RI Baru Terjadi 2021. CNN Indonesia [Internet]. 29 Agustus 2020 [dikutip 17 Juli 2021]; Tersedia pada: https://www.cnnindonesia.com/teknologi/202 00829130346-199-540627/epidemiologprediksi-puncak-COVID-19-ri-baru-terjadi2021

16. C.R M, Kacker P. Emotional Arousal - The Driving Force of Life. J Psychol Clin Psychiatry. 2018;9(1):00505. Tersedia pada: http://medcraveonline.com/JPCPY/JPCPY09-00505.pdf

17. Harvey JA, Cohen MA, Brenin DR, Nicholson BT, Adams RB. Breaking Bad News: A Primer for Radiologists in Breast Imaging. J Am Coll Radiol. 2007;4:800-8. Tersedia pada: https://www.jacr.org/article/S15461440(07)00332-8/fulltext

18. Wen J, Aston J, Liu X, Ying T. Effects of misleading media coverage on public health crisis : a case of the 2019 novel coronavirus outbreak in China. Anatolia [Internet]. 2020;00(00):1-6. Tersedia pada: https://doi.org/10.1080/13032917.2020.17306 21

19. McIntyre KE, Gibson R. Positive News Makes Readers Feel Good: A "Silver-Lining" Approach to Negative News Can Attract Audiences. South Commun J. 2016;81(5):304-15. Tersedia pada: http://dx.doi.org/10.1080/1041794X.2016.117 1892

20. Zhao H, He X, Fan G, Li L, Huang Q, Qiu Q, et al. COVID-19 infection outbreak increases anxiety level of general public in China: involved mechanisms and influencing factors. J Affect Disord [Internet]. 2020;446-52. Tersedia https://doi.org/10.1016/j.jad.2020.07.085

21. Lee SA. Coronavirus anxiety scale: A brief mental health screener for COVID-19 related anxiety Coronavirus anxiety scale: A brief mental health screener for COVID-19 related anxiety. Death Stud [Internet]. 2020;1-9. Tersedia pada: https://doi.org/10.1080/07481187.2020.17484 81

22. Spitzer RL, Kroenke K, Williams JBW, Lo B. A brief measure for assessing generalized 
anxiety disorder. Arch Intern Med [Internet]. 2015;166:1092-7. Tersedia pada: https://doi.org/10.1001/archinte.166.10.1092

23. Budikayanti A, Larasari A, Malik K, Syeban Z, Indrawati LA, Octaviana F. Screening of generalized anxiety disorder in patients with epilepsy: Using a valid and reliable Indonesian Version of Generalized Anxiety Disorder-7 ( GAD-7 ). Neurol Reasearch Int. 2019;2019:1-10. Tersedia pada: https://pubmed.ncbi.nlm.nih.gov/31275648/

24. Shabahang R, Aruguete MS, McCutcheon LE. Online health information utilization and online news exposure as predictor of COVID19 anxiety. N Am J Psychol. 2020;22(3):46982. Tersedia pada: https://pesquisa.bvsalud.org/global-literatureon-novel-coronavirus-2019ncov/resource/en/covidwho-1117880

25. Guez J, Saar-Ashkenazy R, Mualem L, Efrati
M, Keha E. Negative emotional arousal impairs associative memory performance for emotionally neutral content in healthy participants. PLoS One. 2015;10(7):1-14. Tersedia pada: https://journals.plos.org/plosone/article?id=10. 1371/journal.pone.0132405

26. Björkstrand J, Agren T, Fredrik A, Frick A, Larsson E, Furmark T, et al. Disrupting reconsolidation attenuates long-term fear memory in the human amygdala and facilitates approach behavior report. Curr Biol. 2016;26:1-6. Tersedia pada: https://pubmed.ncbi.nlm.nih.gov/27568591/

27. Dresler T, Mériau K, Heekeren HR, Meer E Van Der. Emotional Stroop task: effect of word arousal and subject anxiety on emotional interference. Psychol Res. 2009;73:364-71. Tersedia pada: https://pubmed.ncbi.nlm.nih.gov/18636272/ 